\title{
Analisis Bauran Pemasaran di Rumah Sakit Pendidikan Universitas Hasanuddin
}

\author{
Sabran $^{1}$, Rini Anggraeni ${ }^{2}$ \\ ${ }^{1)}$ Program Studi Rekam Medik, Jurusan Kesehatan, Politeknik Negeri Jember, sabran@polije.ac.id \\ ${ }^{2)}$ Bagian Manajemen Rumah Sakit, Fakultas Kesehatan Masyarakat, Universitas Hasanuddin, \\ rinianggraeni_skm@yahoo.com
}

\begin{abstract}
ABSTRAK
Rumah sakit saat ini tengah dihadapkan dengan era persaingan global diberbagai sektor kesehatan. Tinggi rendahnya pasien baru merupakan permasalahan yang dihadapi bagian pemasaran rumah sakit. Rumah sakit baru yang telah memiliki bagian pemasaran didalamnya dan akan mengembangkan beberapa program pelayanan unggulan, rumah sakit dipandang perlu untuk menganalisis Bauran Pemasaran yang telah diterapkan. Tujuan penelitian untuk menganalisis Bauran Pemasaran. Penelitian ini adalah penelitian deskriptif dengan pendekatan kualitatif melalui teknik in-depth interview, observasi, dan data sekunder. Informan dalam penelitian ini berjumlah delapan yang dipilih melalui teknik puprosive sampling. Hasil penelitian ini menunjukkan bahwa proses pemasaran yang dilakukan belum ada pola khusus. Tarif rumah sakit ditetapkan berdasarkan perhitungan unit cost dari usulan tiap unit. Jarak dan kemudahan mendapatkan pelayanan mudah karena letak poliklinik berada di lantai satu. Jenis promosi yang telah dilakukan diantaranya melalui media brusur, stiker, majalah, website dan kunjungan ke perusahaan. Pengembangan sumber daya manusia disediakan anggaran untuk pelatihan. Rumah sakit juga menyediakan admission untuk kemudahan pelayanan. Pengembangan sarana dan prasarana sesuai dengan kebutuhan pelayanan dilihat dari skala prioritas. Kesimpulanya, semua bauran pemasaran telah diperhatikan oleh rumah sakit dalam penyusunan program pemasaran. Namun, perlu mengoptimalkan produk lain yang belum difavoritkan serta masih perlu meningkatkan promosi melalui media elektronik dan media cetak.
\end{abstract}

Kata kunci: Bauran Pemasaran, Media, Rumah Sakit

\begin{abstract}
Nowadys, hospital is facing of global competiton era in every field. More or less of new patient is one of the problem of hospital. as a new hospital that has a marketing unit and will develop more of excellent service programs, hospital have to do evaluation of mix marketing programs that have implementated. the purpose of this study is. The kind of this study was a descriptive study with qualytatif approach by indeepth interview, observation and secondary data. There were eight respondent that choosen by purposive sampling. The results of this study were marketing process of hasanuddin university hospital was still has not a pattern yet, just promotion. Service price was base on unit cost of every installation. Then, easy to find outpatient installation because it was at the first floor, the kind of promotion media were brochure, sticker, magazine, website and company visitation. There was hospital funding for training to develop of human resources ability, admission for service easily, prepare of facilities by priority scale. The conclusion of this study was all of marketing mix have attentioned by hospital in making of marketing program.But also have to optimalisation of another product that still has not favorite yet and increase of promotion by electronic or mass media.
\end{abstract}

Keywords: Bauran Marketing, Media, Hospital

* Korespondensi Author: Sabran, Politeknik Negeri Jember, sabran@polije.ac.id,Telp.085294045454

\section{PENDAHULUAN}

Rumah sakit dewasa ini sangat dibutuhkan oleh masyarakat yang ingin memperoleh pelayanan jasa kesehatan. Rumah sakit turut berperan penting dalam menciptakan ataupun mewujudkan masyarakat yang sehat dan kuat baik jasmani maupun rohani. Rumah sakit pada kenyataannya tidak jauh berbeda dengan perusahaan lain yang memasarkan barang atau jasa, yang mana tujuannya adalah sama yaitu untuk berkembang, menghasilkan laba dan mempertahankan kelangsungan hidup selain untuk mengabdi pada masyarakat. 
Memperhatikan perkembangan bisnis yang sangat pesat saat ini dan dimasukinya era globalisasi, terdapat tingkat persaingan yang cukup tinggi diantara para pelakunya. Setiap rumah sakit berusaha untuk menjadi yang terbaik dari para pesaing lainnya. Dalam menghadapi persaingan tersebut dibutuhkan suatu perhatian khusus mengenai seberapa jauh pertumbuhan dan kemajuan rumah sakit dalam menghadapi persaingan. Jika tidak maka rumah sakitakan tenggelam dan kalah bersaing atau akan mengalami kebangkrutan.

Melihat fenomena di atas, keunggulankeunggulan yang dimiliki rumah sakit harus mampu memberikan sesuatu yang kreatif dan inovatif, sehingga dapat dimanfaatkan secara optimal dalam upaya memberikan pelayanan terbaik pada pasien, pengunjung rumah sakit lainnya maupun masyarakat luas².

Salah satu cara utama mendiferensiasikan pelayanan jasa kesehatan termasuk rawat jalan adalah memberikan jasa pelayanan kesehatan yang berkualitas, lebih tinggi dari pesaing secara konsisten untuk memberikan kepuasan kepada konsumen. Oleh sebab itu, pengambilan keputusan yang dilakukan oleh pada manajer pemasaran akan selalu berada dalam suatu lingkungan yang ada yang kompleks dan penuh ketidakpastian, sehingga manajer harus mempunyai tingkat pengawasan yang luas terhadap segala aspek dalam pemasaran. Tugas manejer dalam menyusun program pemasaran adalah mengintegrasikan keselarasan yang terbaik antara kemampuan internal dan lingkungan pasar eksternal. Keputusankeputusan yang diambil terutama menyangkut masalah bauran pemasaran yaitu 7P (Product, Price, Place,Promotion, People, Process, and Physical Evidence) harus lebih responsive terhadap kebutuhan pasar ${ }^{3}$.

Jumlah kunjungan rawat jalan rumah sakit Universitas Hasanuddin pada tahun 2011 dapat diketahui jumlah kunjungan lama sebanyak 321 orang dan kunjungan baru sebanyak 499 orang.Selama tahun 2012 dapat diketahui jumlah kunjungan lama sebanyak 5255 kunjungan terus meningkat dengan rata-rata kunjungan per hari sebanyak 18 kunjungan. Kunjungan lama atau PUSLITBANG Sinergis Asa Professional, Jember berulang ini menunjukkan tingkat kepercayaan pelanggan terhadap pelayanan rumah sakit Universitas Hasanuddin yang diberikan, sedangkan jumlah kunjungan baru sebanyak 4303 kunjungan dengan rata-rata kunjungan baru per hari sebanyak 15 kunjungan. Pada tahun 2013 jumlah kunjungan pasien lama sebanyak 15915 kunjungan dengan rata-rata 53 kunjungan tiap harinya, sedangkan jumlah kunjungan pasien baru sebanyak 7933 dengan rata-rata 27 kunjungan tiap harinya ${ }^{4}$.

Kondisi lebih banyaknya kunjungan pasien lama dibanding dengan kunjungan pasien baru merupakan salah satu masalah yang dihadapi oleh manajerial rumah sakit terutama pada bagian pemasaran rumah sakit. Masalah ini mungkin dipengaruhi oleh bauran pemasaran yang diterapkan dirumah sakit tersebut.

Rumah Sakit Universitas Hasanuddin dipandang perlu untuk mengevaluasi bauran pemasaran yang telah diterapkan. Analisis evaluasi kebijakan mengkaji akibat-akibat pelaksanaan suatu kebijakan dan membahas hubungan antara cara-cara yang digunakan dengan hasil yang dicapai ${ }^{5}$.

Penelitian ini bertujuan untuk menganalisis bauran pemasaran di Rumah Sakit Universitas Hasanuddin.

\section{METODOLOGI}

Penelitian ini menggunakan rancangan penelitian deskriptif dengan pendekatan kualitatif melalui teknik in-depth interview (wawancara mendalam). Penelitian ini dilakukan di Rumah Sakit Pendidikan Universitas Hasanuddin pada bulan Maret - April tahun 2014. Informan kunci adalah Kepala Bidang Pemasaran dan Kerjasama. Informan biasa yang akan diwawancarai ada tujuh orang diantaranya Staf Pemasaran dan Kerjasama, Kepala Bidang Pelayanan Penunjang dan Sarana Medik, Kepala Bidang Administrasi Umum dan SDM, Kepala Bidang Keuangan, Kepala Instalasi rawat Jalan, Tim Tarif, dan Admisi.

Saat wawancara, sudah melakukan analisis terhadap jawaban yang diwawancarai. Bila jawaban yang diwawancarai setelah dianalisis terasa belum memuaskan, akan 
melanjutkan pertanyaan lagi, sampai tahap tertentu diperoleh data yang dianggap kredibel.

Pengolahan dan penyajian data mengenai bauran pemasaran di Rumah Sakit Universitas Hasanuddin yaitu dideskripsikan dalam bentuk teks narasi. Digunakan beberapa teknik pengujian keabsahan data yaitu meningkatkan ketekunan dan triangulasi sumber.

\section{HASIL DAN PEMBAHASAN Hasil}

Informan yang terlibat langsung dalam penelitian ini sebanyak delapan orang. Masa kerja informan cukup bervariasi berkisar antara dua tahun sampai empat tahun dengan variasi umur 25 sampai 48 tahun. Sebanyak enam orang informan berjenis kelamin perempuan dan dua orang berjenis kelamin laki-laki.

Berdasarkanhasil wawancara mendalam, data sekunder maupun observasi hasil penelitian sebagai berikut :

Hasil wawancara yang terkait dengan proses pemasaran yang dilakukan belum ada pola khusus, sehingga proses pelaksanaannya masih mengacu pada prioritas publik yang dipromosikan. Sebagaimana penuturan SB sebagai berikut :

"Tidakada pola khusus jadi kita masi mengacu ke mana perioritas untuk kita sampaikan ke publik dengan jenis pelayanan terbatas yang tersedia disini sebagai rumah sakit baru, jadi belum ada pola khusus. Kalau masalah tim tidak ada spesifik, semua terlibat dalam proses pemasaran itu. Jadi bukan hanya petugas pemasaran itu sendiri." (SB, 02 April 2014)

Hasil wawancara yang terkait dengan bauran pemasaran yang diperhatikan oleh rumah sakit dalam penyusunan program pemasaran adalah semuanya bauran pemarasaran yaitu prodak, tempat, promosi, tarif, orang, proses, dan penampilan fisik tetapi lebih cenderung melakukan promosi. Sebagaimana penuturan berikut:

"Dari prodak, waktu belum ada unggulan kita pelayanan dasar kita berikan, mulai rawat, inap rawat jalan, emergency.Dari sisi tarif, kita sesuaikan dengan perkembangan pelayanan. PUSLITBANG Sinergis Asa Professional, Jember
Dari segi tempat sebenarnya akses tidak jadi masalah. Untuk dari segi promosi, promosi kita ada online ada offline, jadi online melalui website, terus untuk offlinemelalui media massa, ada melalui intraksi, ada melalui kunjungan. Tapi kita lebih cenderung ke promosi karena semua tidak terlalu masalah"'(SB 02 April 2014)

Hasil wawancara, observasi dan data sekunder diketahui bahwa jenis pelayanan yang ditawarkan khususnya rawat jalan adalah poli umum dan poli spesialis. Sebagaimana penuturan berikut :

"Di rawat jalan itu ada poli umum, ada poli spesialis sub-sub spesialis misalnya interna itu, ada ginjal hipertensi, ada endokrin metabolik, ada infeksi tropis. Pokoknya ada beberapa sub devisinya, bedah juga begitu ada delapan subdevisi ortopedi, anak pun begitu ada beberapa subdevisinya" (AF 02 April 2014)

Hasil wawancara diketahui bahwa penetapan tarif menggunakan fee for service, karena pada saat itu masih jamannya jaminan kesehatan ASKES. Artinya, pasien-pasien asuransi sistem penetapan tarifnya ditentukan oleh kerjasama antar perusahaan dengan pihak rumah sakit dan perhitungan unit cost melalui usulan masing-masing unit. Sebagaimana penuturan berikut:

"Untuk 2013 kita menggunakan fee for service, karena 2013 itu jamannya jaminan kesehatan ASKES. Ada tifo servis dimana untuk pasien-pasien asuransi penetapan tarifnya ditentukan oleh kerjasama antar perusahaan dengan pihak rumah sakit”" (IS 02 April 2014)

"Jadi setiap instalasi itu memasukkan data-data, tindakan-tindakan serta BHP yang dia gunakan, sudah itu kami tim tarif, dari kesepakatan ada terakhir 2013 itu kalau ada tarif konsultasi ada beberapa perbedaan persentase antara konsultasi sama tindakan khusus di rawat jalan" (AF 02 April 2014)

Hasil wawancara diketahui bahwa metode dan cara pembayaran yaitu pasien umum membayar tunai, sedangkan pasien jaminan menggunakan asuransi. Sebagaimana penuturan mereka berikut:

"Kalau pasien umum setelah ditindaki, setelah melakukan pemeriksaan dia langsung Hal 38 dari 42 
membayar, sedangkan pasien jaminan atau asuransi dia lengkapi semua berkes-berkasnya baru bisa langsung pulang” (MA 04 April 2014)

Hasil wawancara dan observasi, diketahui bahwa jarak dan kemudahan mendapatkan pelayanan pasien rawat jalan akan semakin dimudahkan karena letak poliklinik berada di lantai satu di lobby utama. Di bagian loby telah disediakan information station. Sehingga, segala sesuatu yang menyulitkan bagi pasien dapat ditanyakan dibagian informasi tersebut. Sebagaimana penuturan IS dan YI berikut:

"Untuk kemudahan rawat jalan ini, kami sengaja tempatkan dilantai satu di lobby utama supaya ini memudahkan pembayaran, jadi rawat jalan sini kami sudah mengumpulkan tersendiri admisi, kasir pelayanan, rekam medis sampai dengan lab, dan beberapa penunjang yang berdekatan dengan rawat jalan." (IS 02 April 2014)

Hasil wawancara, observasi dan data sekunder bahwa promosi yang telah dilakukan yaitu melalui media massa, salah satunya membuat pamflet yang berisikan pelayananpelayanan yang tersedia. Kegiatan promosi lainnya juga yaitu dengan melakukan kunjungan langsung ke perusahaan. Sebagaimana penuturan berikut:

"Melalui media massa, kemudian kita juga sedang melakukan promosi yang langsung ke perusahaan, dan kita juga melakukan beberapa kegiatan-kegiatan yang secara tidak langsung adalah targetnya untuk promosi seperti kerjasama-kerjasama dengan melakukan operasi mata, katarak, kemudian operasi gratis, pemeriksaan gratis, seminar-seminar, itu sетиa sebenarnya media untuk promosi dari rumah sakit" (RS 08 April 2014)

Hasil wawancara dan data sekunder diketahui bahwa untuk pengembangan sumber daya manusia dalam rangka peningkatan kualitas dan motivasi pelayanan rumah sakit, maka disediakan anggaran untuk pengembangan sumber daya manusia seperti anggaran pelatihan dan peningkatan skill pada bidangnya masingmasing. Sebagaimana penuturan IS dan RS berikut:
"Untuk pengembangan sumber daya manusia di rumah sakit Unhas kita menentukan anggaran untuk pengembangan SDM, dalam bentuk pelatihan, skill sesuai dengan bidang masing-masing. Untuk kualitas dan motivasi sudah beberapa kita lakukan, eee... beberapa seperti ESQ, ataupun motivasi pagawaipegawai baru” (IS 02 April 2014)

Hasil wawancara, observasi dan data sekunder diketahui bahwa untuk mempermudah proses pelayanan kepada pasien disetiap poli maka disediakan admission khusus untuk rawat jalan. Untuk standar operasional prosedur (SOP) diketahui bahwa setiap bagian pelayanan di rumah sakit Universitas Hasanuddin sudah memiliki SOP masing-masing. Sebagaimana penuturan informan berikut:

"Kami terutama rawat jalan itu berusaha bagaimana pasien-pasien itu tidak susah menerima dalam pelayanan yang di rumah sakit. Betul ada SOP-nya kan kami mau akreditasi" (AF 02 April 2014)

Hasil wawancara dan observasi bahwa cara pengembangan sarana dan prasarana adalah meminta kepada user untuk membuat perencanaan atau permintaan yang dibutuhkan untuk pelayanan. Sebagaimana penuturan berikut:

"Caranya dengan kita meminta user membuat perencanaan atau permintaan apa yang dibutuhkan untuk pelayanan.Diusulkan kalau memang itu dibutuhkan dan sangat urgent, kita bikin berdasarkan skala perioritas sebenarnya. Tapi tentu saja kita utamakan yang standarya" (DB 03 April 2014)

\section{Pembahasan}

Bauran pemasaran merupakan suatu konsep utama dalam pemasaran modern sebagai perangkat alat pemasaran taktis yang dapat dikendalikan dan dipadukan oleh rumah sakituntuk menghasilkan respon yang diinginkan dalam pasar sasaran. Terkait dengan bauran pemasaran yang diperhatikan oleh rumah sakit dalam penyusunan program pemasaran. Segi produk ini semuanya masih standar dan disediakan di rumah sakit lain. Segi tarif pada awalnya masih sangat terjangkau kemudian 
selanjutnya disesuaikan dengan perkembangan pelayanan. Segi tempat cukup baik karena lokasinya mudah diakses sehingga jarak jangkauan tidak menjadi masalah. Segi promosi yaitu promosi melalui online dan offline. Promosi online yaitu melalui website interaktif. Sebenarnya rumah sakit juga sudah memiliki media sosial, namun belum terupdate. Kondisi ini terjadi karena masih kekurangan personil dari bidang pemasaran. Promosi offline yaitu melalui media massa atau intraksi langsung bahkan biasanya dilakukan kunjungan. Kunjungan ke perusahan telah dilaksanakan untuk melakukan kerjasama. Rumah sakit juga melakukan kerjasama dengan asuransi dan klinik-klinik. Contohnya klinik penunjang priodia dan klinik mata orbita. Semuanya bauran pemarasaran akan diperhatikan yaitu prodak, tempat, promosi, tarif, orang, proses, dan penampilan fisik tetapi lebih cenderung melakukan promosi.

Bauran pemasaran ternyata memiliki peranan penting terhadap keputusan pasien memilih rumah sakit. Tinggi rendahnya keinginan konsumen atau masyarakat memakai suatu prodak jasa pada rumah sakit berdasarkan penerapan marketing mix yang ada. Hal ini disebabkan karena salah satu unsur marketing mix yaitu pada unsur promotion. Bagaimana pun berkualitasnya suatu produk, harga maupun tempat yang ada pada rumah sakit jika penyampaian informasi pada masyarakat masih kurang efektif tentu akan berpengaruh terhadap keputusan pasien memilih rumah sakit, karena kurangnya informasi yang didapatkan ${ }^{6}$.

Hasil wawancara, observasi dan data sekunder diketahui bahwa jenis pelayanan yang ditawarkan rumah sakit Universitas Hasanuddin khususnya rawat jalan adalah poli umum dan poli spesialis. Untuk poli spesialis yang ditawarkan hampir sama dengan rumah sakit lain yang disertai juga dengan sub-sub spesialis.

Produk adalah segala sesuatu yang dapat ditawarkan produsen untuk diperhatikan, diminta, dicari, dibeli, digunakan atau dikonsumsi pasar sebagai pemenuhan kebutuhan atau keinginan pasar yang bersangkutan ${ }^{7}$.

Hasil wawancara diketahui bahwa penetapan tarif di rumah sakit Universitas PUSLITBANG Sinergis Asa Professional, Jember
Hasanuddin menggunakan fee for service, karena pada saat itu masih jamannya jaminan kesehatan ASKES. Artinya, pasien-pasien asuransi sistem penetapan tarifnya ditentukan oleh kerjasama antar perusahaan dengan pihak rumah sakit. Selain itu,tarif rumah sakit Universitas Hasanuddin ditetapkan berdasarkan perhitungan unit cost juga. Cara penetapannya yaitu setiap instalasi memasukkan data-data, tindakan-tindakan serta BHP yang digunakan, setelah itu tim tarif menyusun tarif berdasarkan laporan dari instalasi. Kemudian membandingkan dengan tarif rumah sakit lain.Harga merupakan sejumlah uang yang dibebankan atas suatu produk atau jasa, atau jumlah dari nilai yang ditukarkan konsumen atas manfaat-manfaat karena memiliki atau menggunakan produk atau jasa tersebut ${ }^{8}$.

Hasil wawancara dan observasi, diketahui bahwa jarak dan kemudahan mendapatkan pelayanan pasien rawat jalan akan semakin dimudahkan karena letak poliklinik berada di lantai satu di lobby utama dan semua rawat jalan berada dalam satu tempat. Di bagian depan telah disediakan information station. Sehingga, segala sesuatu yang menyulitkan bagi pasien dapat ditanyakan di bagian informasi tersebut. Selain itu, setiap petugas di rumah sakit telah diberi edukasi agar mampu memberikan informasi tentang apapun yang dibutuhkan pasien. Akses pasien sangat mudah, dari segi pelayanan pasien sangat dimudahkan kerena tidak ada perbedaan pelayanan kepada pasien.

Tempat terjadinya transaksi (rumah sakit) mempunyai arti penting karena lingkungan tepat jasa akan disampaikan dan cara jasa disampaikan merupakan bagian nilai dan manfaat jasa yang dipersepsikan pelanggan. Keputusan-keputusan lokasi dan saluran distribusi meliputi pertimbangan mengenai cara menyampaikan jasa kepada pelanggan dan di mana jasa akan ditempatkan. Tempat dan distribusi terkait dengan keputusan rumah sakit atau perusahaan mengenai di mana operasi dan stafnya akan ditempatkan?.

Hasil wawancara, observasi dan data sekunder bahwa promosi yang telah dilakukan di rumah sakit Universitas Hasanuddin yaitu 
melalui media massa, salah satunya membuat brosur yang berisikan jenis pelayanan yang tersediah di rumah sakit Universitas Hasanuddin serta menempatkan pada tempat-tempat yang strategis dan mudah dijangkau oleh pengunjung rumah sakit. Selain itu, ada beberapa majalah yang mempromosikan pelayanan rumah sakit dan setiap pintu lift terdapat poster yang memperkenalkan jenis pelayanan unggulan. Kegiatan promosi lainnya juga yaitu dengan melakukan kunjungan langsung ke perusahaan dan memberikan pelayanan secara gratis untuk pemeriksaan-pemeriksaan tertentu.

Promosi dalam konsep strategi pemasaran merupakan unsur taktik pemasaran dalam upaya menangkap pasar. Hasil akhir promosi adalah akses pasar pada pelayanan kesehatan. Indikator keberhasilan promosi adalah meningkatnya kunjungan rumah sakit (rawat jalan dan rawat inap $)^{9}$.

Hasil wawancara dan data sekunder diketahui bahwa untuk pengembangan sumber daya manusia dalam rangka peningkatan kualitas dan motivasi pelayanan rumah sakit, maka disediakan anggaran untuk pengembangan sumber daya manusia seperti anggaran pelatihan dan peningkatan skill pada bidangnya masingmasing. Bidang sumber daya manusiabekerjasama dengan bidang pendidikan dan pelatihan. Beberapa pelatihan yang biasa dilakukan seperti komunikasi efektif, ESQ, simposium, workshop dan seminar-seminar. Jadi, setiap bagian di rumah sakit bertanggung jawab memberikan penembahan ilmu kepada setiap stafnya. Sehingga, jika terdapat masalah secepatnya dilakukan evaluasi. Beberapa kekurangan yang didapatkan kemudian diberikan pelatihan sesuai dengan bidangnya. Pelatihan seperti ini terus ditingkatkan tiap tahun sesuai kebutuhan sumber daya manusia rumah sakit.

People sebagai unsur pemasaran dikaitkan dengan pemasaran internal. People ialah upaya untuk meningkatkan perilaku efektif karyawan dan depertemen rumah sakit yang dapat menarik pelanggan. Oleh karena itu, rekrutmen, seleksi, pelatihan dan motivasi, serta manajemen sumber daya manusia merupakan strategi untuk meningkatkan perilaku efektif ${ }^{9}$.

Hasil wawancara, observasi dan data sekunder diketahui bahwa untuk mempermudah proses pelayanan kepada pasien disetiap poli maka disediakan admission khusus untuk rawat jalan. Admission yang akan mengarahkan pasien ke palayanan yang akan di kunjungi. Selain mengarahkan pasien, admission juga dapat dimanfaatkan pasien dan keluarga pasien untuk memperoleh informasi seputar rumah sakit dan jenis pelayanan yang disediakan. Kemudahan pelayanan rumah sakit juga membuat standar operasional prosedur. Standar operasional prosedur (SOP) diketahui bahwa setiap bagian pelayanan di rumah sakit Universitas Hasanuddin sudah memiliki SOP masingmasing. Setiap SOP dibuat semudah mungkin untuk pelayanan rumah sakit. Oleh karena itu, pelayanan medik dan penujang juga telah ada SOP-nya dan semua petugas rumah sakit mengacu pada SOP tersebut.

Proses dimana jasa disampaikan kepada pelanggan merupakan faktor utama didalam bauran pemasaran jasa. Karena pelanggan akan seringkali mempersepsikan sistem penyampaian jasa sebagai bagian dari jasa itu sendiri. Proses merupakan gabungan dari semua aktifitas, umumnya terdiri dari prosedur, jadwal pekerjaan, mekanisme dan aktifitas dimana jasa dihasilkan dan disampaikan kepada konsumen ${ }^{10}$.

Hasil wawancara bahwa cara pengembangan sarana dan prasarana adalah meminta kepada user untuk membuat perencanaan atau permintaan yang dibutuhkan untuk pelayanan. Setelah itu, akan usulkan namun harus tetap melalui rektorat. Pengusulan akan diajukan jika dianggap betul-betul dibutuhkan dan sangat urgent. Artinya membuat skala prioritas, dengan mengacu pada standar yang telah ada.

Physical evidence merupakan tampilan fisik yang dapat mempengaruhi keputusan pembeli dari produk yang ditawarkan. Bukti fisik adalah struktur fisik dari sebuah perusahaan yang merupakan komponen utama dalam membentuk kesan sebuah perusahaan. Bukti fisik merupakan keadaan nyata pada suatu 
perusahaan seperti bangunan, interior, peralatan, bahkan pakaian seragam ${ }^{11}$.

\section{SIMPULAN DAN SARAN}

Penelitian ini menyimpulkan bahwa proses pemasaran yang dilakukan di Rumah Sakit Universitas Hasanuddin belum ada pola khusus, sehingga proses pelaksanaannya masih mengacu pada promosi. Terkait dengan bauran pemasaran yang diperhatikan oleh rumah sakit dalam penyusunan program pemasaran adalah semua bauran pemasaran yaitu produk, tempat, promosi, tarif, orang, proses, dan penampilan fisik, tetapi lebih cenderung melakukan promosi.

Pihak rumah sakit agar mengoptimalkan promosi dan kualitas layanan poliklinik yang lainnya selain poli onkologi dan radiologi sehingga semua produk yang ditawarkan di rumah sakit difavoritkan. Perlu memberikan informasi-informasi yang jelas terkait dengan adanya kelonggaran atau potongan harga yang diberikan kepada pasien pada event-event tertentu. Meningkatkan promosi melalui media elektronik dan media cetak. Serta meningkatkan fasilitas rambu-rambu atau petunjuk tentang letak rumah sakit dan poliklinik.

\section{UCAPAN TERIMA KASIH}

Peneliti mengucapkan terima kasih kepada Rumah Sakit Pendidikan Universitas Hasanuddinsebagai tempat penelitian, peneliti juga berterima kasih kepada semua pihak yang telah membantu terselesaikannya artikel ini.

\section{REFERENSI}

1. Kemenkes RI. Profil Kesehatan Indonesia. Jakarta: Kementerian Kesehatan RI;2013.

2. Arifin S. Pengaruh Manajemen Stratejik dalam Upaya Meningkatkan Tingkat Hunian Rawat Inap PS Islam A. Yani Surabaya. Jurnal Manajemen. 2007:32 (2);15.

3. Rumah Sakit Universitas Hasanuddin. Laporan Kinerja. Makassar; 2012

4. Fatmawati, Dian. Studi Persepsi Staf Manajemen Manajemen Rumah Sakit Universitas Hasanuddin Makassar Tentang Manajemen Pemasaran Rumah Sakit [Skripsi].Makassar: Universitas Hasanuddin;2012.
5. Hasibuan, Mariani. Peranan Marketing Mix Terhadap Keputusan Pasien Berobat Pada Rumah Sakit Umum Daerah Rokan Hulu.Jurnal Ekonomi. 2012: 24 (5); 6.

6. Kotler, Philip. Dasar-dasar Pemasaran.Jakarta: Prenhallindo;2000.

7. Kotler,Philip dan Keller, KL. Marketing Management, $12^{\text {th }}$ Edition, prentice Hall, New Jersey;2006.

8. Supriyanto.Pemasaran Industri Jasa kesehatan,Yogyakarta: CV. Andi Offset;2010.

9. Lupiyoadi, Rahmat\& Hamdani, A. Manajemen pemasaran Jasa,Jakarta:Salemba Empat;2006.

10. Fandy, Tjiptono. Pemasaran Jasa Rumah Sakit.Malang: Bayumedia Publishing Malang;2005

11. Sugiyono. Metode Penelitian Manajemen, Bandung: Alfabeta;2013.

12. Hartono, Bambang. Manajemen Pemasaran untuk Rumah Sakit.Jakarta: Rineka Cipta; 2010.

13. Salmiah WD.N. Analisi Proses Penyusunan dan Implementasi Manajemen Pemasaran Di Rumah Sakit Unhas Kota Makassar [Skripsi]. Makassar: Universitas Hasanuddin; 2012. 